They were concerned with the failures of communication that seem to occur between the patient and his doctors. Having reviewed the literature on this subject and made their own observations, they then carried out some limited studies on patients, followed by some more controlled experiments on volunteers and finally returned to the clinic to test out the findings from the first two studies-an excellent example of the progression of applied research. They found that patients, asked as they left the surgery what the doctor had told them, were grossly inaccurate in their recall of the instructions given to them. In this short interval they had forgotten altogeher one-third of everything that they had been told and a half of the of ten truly vital instructions. Later experiments indicated that the amount remembered is to some extent an inverse function of the total amount of information supplied (moral: we must limit our instructions and information to the essentials); that writing down information does not hinder (or, indeed, aid) recall (moral: we should encourage writing of the most essential items so that the client has a permanent record to refer to when memory fails); that the patient's level of anxiety is a potent factor in determining how much is remembered (moral: we must become sensitive to anxiety and aim to reduce it to increase our communication strength); and that the position of items in the total group of instructions is a major factor in whether or not there is recall-the earliest items in the list being recalled best. Return to the clinic with methods of imparting information modified along these lines yielded the encouraging result that now the important information was better recalled than before. By modifying their communication techniques in accordance with the experimental findings, Ley and Spelman had achieved an improvement in the doctor/patient relationship as well as pointing the way for further joint work by psychologists and general practitioners.

Obviously it is too early to think of every general practitioner having a psychologist at hand, but already many group practices have one on call. Clinical psychologists at local hospitals will often welcome inquiries for their services in behavioural problems especially as this is consistent with their increasing involvement with the community beyond the hospital walls.

This article is based on a lecture given in the Birmingham course under the title "The Scientific Basis of Clinical Practice" (see B.M.F. 27 November 1971, p. 510).

\section{References}

1 Lombroso, C.. L'homme Criminel, Paris, Felix Alcan, 1887

Hastorf, A., Schneider, D. J., and Polefka, Judith, Person Perception. Reading, Mass., Addison-Wesley, 1970.

3 Darwin, C., The Expression of the Emotions in Man and Animals. London, Murray, 1872

- Feleky, A. Psychological Review, 1914, 21, 33.

5 Ulrich, L., and Trumbo, D., Psychological Bulletin, 1965, 63, 100.

- Lansing, J. B., and Blood, D. M., The Changing Travel Market. University of Michigan, Survey Research Centre, Monograph 38, 1963.

7 Cannell C. F. Survey Research Centre, Monograph in Three Survey Procedures. Vital and Health Statistics, series 2, no. 8 . Dept. of Health, Education, and Welfare, Nation Center for Health Statistics, 1965.

s Madow, W. G., Interview Data on Chronic Conditions Compared with Information Derived from Medical Records, Vital Health Statistics series 2, No. 23, U.S. Dept. of Health, Education, and Welfare, National Center for Health Statistics, 1967.

${ }^{9}$ Vernon, P. E., Fournal of Social Psychology, 1933, 4, 42

10 Estes, S. G., Fournal of Abnormal and Social Psychology, 1938, 33, 217.

11 Rutter, M., and Brown, G. W., Social Psychiatry, 1966, 1, 38.

12 Rutter, M., and Graham, P., British 7ournal of Psychiatry, 1968, 114, 563

13 Lev, P., and Spelman, M. S., Cominunicating with the Patient, London, Staples, 1967.

\title{
Days Past
}

\section{Life and Death in Shakespeare's London}

\author{
W. H. MCMENEMEY
}

British Medical fournal, 1972, 1, 795-796

Among the many treasures stored in the Guildhall Library lie the old parish records of St. Botolph without Aldgate. They are now made available to a wide circle of readers thanks to the research of Dr. Thomas Rogers Forbes, who has recently published his account of them. ${ }^{1}$

In the reign of Elizabeth and James I the chroniclers of this 45-acre parish were part-time clerks, and their formal catalogues of human events were often spiced with comments founded on gossip and personal observation. John Clerke, who began his service in 1616, was a girdler with a caustic pen and a watchful eye for premarital conception. One bride and her groom he described as "two beggars both of the Scumm of our parish," while another bride was "a peece of Crackt Stuff." But for unfortunate Anthony Haddocke, the product of "a Base Strumpet" by "a base varlet," he penned this prayer in the margin: "God send the Child more grace then the wicked Parents." Of an unmarried mother who was delivered under the church wall one January night he wrote "There are too manie . . . now adayes, more is the pittie," and of a musician, "a heavie widower the space of three whole weekes;" he added that he would have married earlier but "he was loth to be at the charg of a licence." Clerke's beautiful handwriting ceases to adorn the parchment pages abruptly-and ominously-in the plague year of 1625 .

These records of St. Botolph parish, as disclosed by Dr. Forbes, are important because they are virtually day books rather than the simple parish registers introduced in 1538 on the command of Thomas Cromwell. Thomas Harridance, an ironmonger, was the clerk (". . . a verie Careful and Industrious man in his place") on 9 February, 1586 when he reported the "Ringinge for Ieoye that the queene of Skotte was beheaded," and there are also other references to contemporary events outside the parish. Religious sectarian prejudice of the time is shown in 1617 when "a young Maid of the Minories-street" is buried at night and without a service "because she was accompted to be a Recusant."

\section{Causes of Death}

In determining the cause of death the clerk sought the advice of "the Searchers" ("antient women, sworn to their office".Graunt ${ }^{2}$ ), who formed their own opinion at the corpseside, taking due note, one supposes, of gossip and scandal. If necessary he would convene a "crowner's quest." Dr. Forbes's analysis of the causes of the 4,253 deaths which occurred in the period 158399 shows that the plague accounted for $23.6 \%$, followed by 
consumption, "pining" and "long sickness," ague, flux, smallpox, and "childbed" ( $1.5 \%$, representing $2.35 \%$ of births). Less usual reasons for death included bleach, purples, mother, planet, toes off, thought, canker of privities, and heaving of lights. No cause was given in $14.1 \%$ of cases. In spite of the obvious unreliability of diagnosis the value of these records is apparent when one is reminded that with few exceptions no weekly bills of mortality in London have survived before 1603 .

Textile manufactories including silk mills claimed a fair number of workers, but the variety of occupations is surprising and would challenge the organizing ability of shop stewards and the competence of the Department of Employment and Productivity. There were hoy men, hotpressers, swaddlers, freemasons, inkhorn makers, cornmeters, fellmongers, spurriers, pointmakers, spice garblers, tipsters, and snaphance makers, while one minor functionary held the title of "letter post for France." There was still the occasional armourer, fletcher, and bowyer within this compact parish, which could boast of a poet, a pursuivant, a pettifogger, and a midwife called "Mrs. pullett." In the street it might be difficult to distinguish a firkinman from a tunman off duty or a professor of physic from a genuine apothecary, but a single woman on the beat would quickly be recognized and avoided, one hopes, as would all masterless men and apple-squires.

In a period of 51 years there were 111 deaths which were clearly not due to natural causes. Of the 55 deemed to be accidental 21 were caused by drowning, one of them a 3-year-old girl who fell in the town ditch when her chair in a privy "whelmed backward." Surprisingly, only four children died of burns. Street accidents accounted for very few deaths but it would seem that pedestrians were at special risk if they went through a city gate alongside a horse-drawn vehicle. Dutchmen, Frenchmen, and Negroes were among those buried in this riverside parish, while sailors, either as assailants or victims, accounted for a fair percentage of the homicides. Of 16 men executed the Wapping dock gallows claimed 13 for piracy. There was one woman hanged together with her husband because she had beaten their serving maid to death-presumably he was deemed to be responsible for her criminal action. On the other hand, "a Murderous strumpett" who attempted to drown her illegitimate daughter in a privy was "arraigned but escaped death." Two girls were murdered by rapists, but the illegitimacy rate in one decade was apparently only $1 \cdot 61 \%$.

\section{Coroner's Court}

The coroner's court went to some pains to assess risks (“ $\ldots \mathrm{w}^{\mathrm{ch}}$. pond lying open near the sayd stable was verie dangerous for children ...") and to anticipate accidents. Nor was a charge of suicide placed lightly on a deceased person, because that entailed being "putt in the ground" surreptitiously at night without benefit of a service. Indeed the coroner might direct that the site of burial be indicated by a stake driven through the chest. Evidently this officer of the law could command a special privilege as when in 1600 Thomas Wilbraham "crowner for the cittie" in the church of St. Botolph "did pannell a crowners quest ... for that he was hurt in the Left Legg wt a butchers sett being throwne at him in white chapel parish."

There were occasional surgical misadventures. In 1588 "the Bowells of Sir William Wenter Knyght were ... Buried on the north syde of the churche ...." A memorandum of the previous day recorded his death at home-“. . . being Cutt of the collick and the Stone." In the absence of a national accident service John Bowes could count himself fortunate to "Lye at surgeries" in a minstrel's house when hurt by "a peece of a chamber" of a small ceremonial cannon. He died eight days later, however, in spite of-or perhaps because of-amputation of the leg. "Goon poulder" was clearly a dangerous commodity in Shakespeare's day. One man was killed when "an old Barrell of a peece" which happened to be charged blew up in the forge, while another was hurt at the maypole when he fired his "peece" and exploded some powder which he was carrying in his sleeve. Although he survived for 24 years an inquest was held after his demise.

\section{Conclusion}

The evidence is clear that the parish officers were conscientious. If they could not identify a stripling lying dead in Peter Miller's hayloft they took care to bury "Marie a chylde ... founde in the streete beyond the Widowe carltons Dore ... near a Dunghill ... being a crisom and being jawsfallen." But in this slender volume one senses not only the tragic end of numerous forgotten persons but also the life and bustle of an artisan community, happy at times in their work and play. Dr. Forbes, who came many times from Yale to spend his leisure hours in the Guildhall Library, is to be congratulated on this valuable and very readable sociological study of a period of our history which is common to his country too. The material is fully documented and is arranged under different headings so that the sequence can be seen against the series of enactments which prescribed an increasing amount of parochial relief for the needy and sick while retaining the whip for the rogues and sturdy beggars.

\section{Reference \\ 1 Forbes, T. R., Chronicle from Aldgate. New Haven, Yale University Press, 1971 . \\ Graun, John, Natural and Political Observations on the Bills of Mortality, 1759. Reprinted from 6th ed. 1676. In $A$ Collection of the Yearly Bills of Mortality, from 1657 to 1758 Inclusive ... ed. Thomas Birch. London, A. Millar}

\section{LORD HAVE VERCY UPON US.}

This is the humble Petition of Englend unto Alm key God, meekely imploring his Divine bounty for the celtation of this Mortality of Peftilence now raigning amongt us : VVith a lamentable Lit of Deaths Triumphs

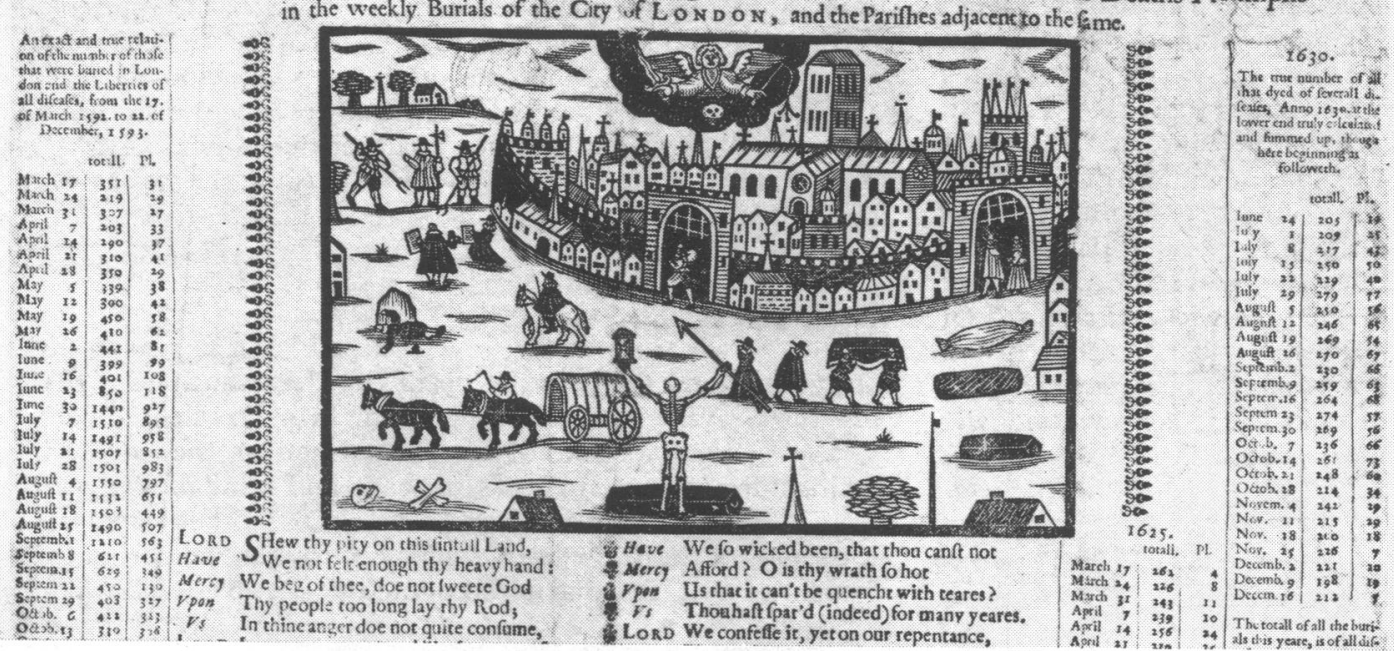

A plague bill, not previously reproduced, probably from 1636 . The disposal of plague victims outside the City walls takes place under the baleful observaion of Death and a destroying weapons (Guildhall Library, weapons (Guildhall
Broadside 28.48.). 